\title{
Sustainable HR development to support successful implementation of offline accounting apps by rural enterprises in Indonesia
}

\author{
Iskandar Muda \\ Department of Accounting, Universitas Sumatera Utara, \\ Medan, Indonesia \\ isk.andar1@usu.ac.id
}

ORCID 0000-0001-6478-9934

\section{Erlina Erlina}

Department of Accounting, Universitas Sumatera Utara,

Medan, Indonesia

erlina@usu.ac.id

ORCID 0000-0002-0495-8836

Abstract. As of 2020, there are still 13,000 villages in Indonesia which until now do not have Internet access. The absence of Internet networks makes economic empowerment difficult. This is the main obstacle for the implementation of online-based accounting systems in rural areas. The background of this research is that sustainable rural development begins with the effort to empower human resources as the key determinants in the successful implementation of offline accounting applications needed by the Rural Enterprises Institute in Indonesia. Successful implementation of accounting systems begins with the implementation of offline mode accounting. This is because rural areas are geographically different and have unequal quality of the telecommunication infrastructure. This research aims to determine the factors affecting the successful implementation of offline accounting applications in aural enterprises (BUMDes) in Indonesia. The research data were collected using questionnaires. There was a total of 336 questionnaires collected back in 2018 to be further processed. The hypotheses were analyzed using Structural Equation Model (SEM) with the assistance of software Smart PLS 3.0. The findings of this research suggest that such constructs as Understanding of the Single-Entry Concept, Understanding of the Double-Entry Concept, Poor Human Resources and Technological Illiteracy influence the implementation of accounting applications. The practical conclusion of this research are that related stakeholders should be developing and implementing offline-based financial reporting accounting systems in an effort to empower human resources in rural economic institutions. Novelty produced here in the form of Sustainability Development model dimensions for offline-based 
accounting system development covers such aspects as Single Entry Concept, Double Entry Concept, Human Resources, technical aspects, and training.

Keywords: double-entry concept, technological illiteracy, successful implementation, offline accounting apps.

JEL Classification: J24, O18

\section{INTRODUCTION}

Rural development aims to improve the welfare of village communities and the quality of human life; it also aims to alleviate poverty through meeting basic needs, building village facilities and infrastructure, developing local economic potential, as well as sustainable use of natural and environmental resources. The development of an economic basis in rural areas has long been carried out by the governments through various programs. However, it has not provided the desired satisfactory results. Many factors led to the lack of success of these programs, one of the most dominant factors being too much government intervention. Consequently, it inhibited the creativity and innovation of rural communities in managing and running the economic machinery in rural areas (Ho et al., 2019, Lyon-Hillet al., 2019, Tang, 2019, Wei \& Li, 2019 and Zhang et al., 2019). The system and the mechanism of economic institutions in rural areas do not work effectively and have an inclination for dependence on government assistance so that it turns off the spirit of independence. The center of the economy in rural areas is the establishment of economic institutions that are fully managed by village communities. In order for these economical institutions not to be controlled by certain groups that have large capital in rural areas, the ownership of village institutions is jointly controlled with the aim of improving economic standards of community life for all.

The key problem of rural development is that not many local assets are directly controlled by rural communities themselves, rural communities have limited access to economic resources such as land, capital, production inputs, skills, technology and cooperation networks (Zhang et al., 2004, Cunningham et al., 2008, Steiner \& Atterton, 2015, Vixathep et al., 2019). On the other hand, low availability of infrastructure and low quality of human resources, weakness of institutions and community-based organizations as well as weak coordination in the development of rural areas become additional problems of the villages. Rural development is carried out under the multilateral (holistic), participatory approach, based on the spirit of independence, environmentalism, sustainability, harmonious and synergic use of development resources.

Regulation of the Minister of Home Affairs No. 39 of 2010 concerning Village-Owned Enterprises (BUMDes) specifies that BUMD is a village-owned enterprise established by the village government whose capital management is undertaken by the village government and the community of the concerned village. BUMD is formed with a view of making a significant contribution to improving the welfare of rural communities and preventing the development of capitalist business systems in rural areas that can lead to disruption of the unique local social life. According to the data from the Ministry of Finance, until 2017 there was a total of 94,954 villages nationwide. Of this total number, 18,000 have active BUMDes all over Indonesia. There is a large number of active BUMDes in Indonesia, therefore, it is required to make monthly financial statements of their business units, and these financial statements must be prepared in an honest and transparent manner. In addition, BUMDes are required to report on the progress of their business units to villagers through village meetings held at least 2 times a year. In practice, the establishment of BUMDes by the village government is mandated in the Law No. 6 as of 2014 (Budionoet al., 2015). To make sure BUMDes are managed efficiently, neatly, and transparently, it is necessary to develop and use applications that are not necessarily connected to the Internet (have the so-called offline mode). Besides, such apps 
should be easy in use by the management of BUMDes (Adisasmita, 2006). The existing applications include Excel-based simple applications, MYOB Accounting, Accurate Accounting, and free applications from the Ministry of Villages and the Supervisory Body for Finance and Development (BPKP).

Purnamasari (2016) states that from the Villages, Development of Disadvantaged Regions as quoted from the news release at www.bpkp.go.id stated that generally, BUMDes faces problems in accessing, developing, and processing information. He asserted that lack of information led to poor effectiveness and efficiency of the BUMDes management. Moreover, for stakeholders, lack of information/information asymmetries leads to poor transparency and accountability of the concerned BUMDes. The use of information technology can cut transaction costs and enable BUMDes to access information about markets more effectively. Based on the description above, it can be concluded that there are a number of factors that affect the successful implementation of the offline accounting applications in Village-Owned Enterprises in Indonesia, namely the Understanding of the Single-Entry Concept, Understanding of the Double-Entry Concept, Poor Human Resources, and Technologically Illiterate with Training in How to Use Accounting Applications as the moderating variable on the Successful Implementation of Accounting Applications. Therefore, the problem formulation in this research is whether the variables Understanding of the Single-Entry Concept, Understanding of the Double-Entry Concept, Poor Human Resources, and Technologically Illiterate with Training in How to Use Accounting Applications as the moderating variable affect the Successful Implementation of Accounting Applications. Offline based accounting software is an accounting software that is permanently installed on a computer. The advantage of this software is that it has good performance because it runs based on the hardware specifications installed on the computer. Another plus is that this software does not require an Internet network so it can be opened outside the existing network. With the appropriate computer specifications, this software can run well without any interference. The disadvantage of offline accounting software is that it cannot be accessed remotely if there is a need to monitor or retrieve a database. In addition, this software cannot be shared because it has different serial numbers from one another for different computer devices. Offline based software based on user experience is very effective for rural institutions in mountainous geography and unstable weather. Also in terms of operators who rarely travel outside the offline mode area is better than online.

Given the importance of accounting information systems in providing valuable business information, especially village companies, reliability or reliability is very important. Especially the data stored in the system usually concerns the privacy and business continuity of a company. The American Institute of CPA and the Canadian Institute of Chartered Accountants (CICA) have identified five basic principles that are important for the reliability of this system, for instance,(1) Security, namely access to the system and the data is controlled and limited to authorized persons, (2) confidentiality that is protection of sensitive information from unauthorized disclosures. (3) Privacy, namely the collection, use and disclosure of personal information about customers is carried in a proper and private manner. (4) Integrated process (5) Processing of accurate, complete and timely data is carried out with the right authorization. (6) availability of systems to meet operational obligations under the contract. The importance of accounting information systems in a company is something that cannot be ruled out. Therefore, choosing the right accounting software and in accordance with business needs is a crucial factor. Cloud-based accounting software that has been widely used by multinational companies to SMEs (Young, 1993 and Zubovic and Jovanovic, 2019). Without the need to install and can be used anytime, anywhere. It can be used on any operating system, starting from Mac, Windows, even Linux. This can be applied if it has a good Internet network. Large rural areas in Indonesia have not supported this. Then the solution for Offline applications is an option, especially for rural companies. This research is different from the results produced by Young (1993) and Zubovic and Jovanovic (2019) where the successful application of accounting systems in rural institutions is determined by the use and application of cloud computing. The research is that the application of accounting 
applications based on cloud computing cannot be applied with various obstacles in the form of aspects of human resources that are not possible and constrained internet networks that are able to reach rural areas. The results expected from this paper contribute to the fact that the offline network model is needed for sustainable development in rural institutions.

\section{LITERATURE REVIEW}

\subsection{Accounting Information Systems}

Accounting Information Systems are processes for data collecting, data processing into information and distributing that information to users (Muhammadet al., 2019). The purpose of the accounting information system is to collect, store, process financial and accounting data to produce reports /information that can be used by stakeholders in making business decisions. In the past, accounting records mostly used manual systems, but along with disruption along with the industrial revolution, now most accounting information systems have used automation (Ghorbel, 2019 and Holsapple, 2019). Function of Accounting Information Systems namely, the first function is efficient and effective collection and storage of data regarding organizational financial activities, including obtaining transaction data from source documents, recording transactions in journals, and posting data from journals to ledgers. The second function is to provide information that is useful for making decisions, including producing managerial reports as well as financial statements, for example, the profit-loss report and the third function is this system ensures that your business transaction data is recorded and processed accurately and safely. Accounting Information Systems consisting of revenue cycles, expenditure cycles, production cycles, financing cycles and general ledger and reporting systems will be easily integrated and run simultaneously if there is a menu that is able to operate together at one time.

\subsection{Sustainable Development}

The objective of Sustainable Development is to sustainably improve the economic welfare of the community, maintain the sustainability of the social life of the community, maintain the quality of the environment as well as inclusive development and implement governance that is able to maintain the improvement of the quality of life from one generation to the next (Nurlina et al., 2019). Sustainable development lies in the issue of how the environment should be treated in order to play a role in economic sustainability as a resource for improving living standards. Kimbuet al., (2019) state that the development of human resources has an important role in realizing advanced and independent human beings so that they can be competitive in the era of globalization. Cetinel et al., (2008) state that the scholastic development educational is an investment in improving the quality of human resources so that it plays an significant role in increasing economic growth and reducing poverty and unemployment. Scholastic development educational is directed at improving the quality of human resources to support the realization of a society that is noble dignified, aristocrat, and values diversity so that it can compete in the global era while remaining based on the norms of society and without discrimination (Ding et al., 2001, Hanh, 2019 and Williams, 2019). Government commitment to education must be reflected in the quality of human resources, improvement in the quality of science and technology. Quality human resources are human resources that have expertise, professionalism, are productive and independently compete are able to healthily in the world of work. Human Resources affect the activities that will be carried out by human resources itself. 


\subsection{Rural Empowerment with Rural Enterprises}

Rural Enterprises are business entities who seen tire or part of their capital is owned by the village through direct capital participation coming from the village's wealth (Psychogios \& Prouska, 2019, Zhu \& Warner, 2019). This institution is predicted to be a force that will be able to encourage of improved welfare by economic productivity in the village based on the variety of potential that the village. Cheah et al., (2019) state that the rural enterprise was born as a village institution that functions to create the welfare of citizens by utilizing assets and potential owned by the village and armed with capital from the village. Empowerment is an increase in people's independence based on the capacity and internal strength of the people for both material and non-material human resources through capital redistribution. Therefore, empowerment is individual and collective. Empowerment is also a process that involves changing power relations between individuals, groups and institutions. Empowerment is easier explained when humans are in a state of powerlessness, helpless, unable to help themselves, losing the ability to control their own lives. Community empowerment is one of the program soft village government in utilizing all available resources in order to develop and can help the process of village progress (García-Cortijo et al., 2019). The targets in this community empowerment program cover all fields, starting from the government, institutions, health and economy of the community (Knight et al., 1999 and Xheneti et al., 2019).There are three approaches to empowering rural communities: First, a directed approach, meaning community empowerment must be directed at siding with the poor; Second, group approach, meaning together to facilitate the solving of the problems faced; Third, the mentoring approach, meaning during the process of forming and organizing a group of poor people, they need to be accompanied by professional assistants as facilitators, communicators and dynamists for the group to accelerate the achievement of independence community empowerment in the area of village governance includes all the resources that exist in village governance such as village heads and village officials (McDonagh \& Commins, 1999, Kimando et al., 2012, Su et al., 2019). This form of an empowerment can be in the form of training, deliberation in the preparation of village programs, coordination in implementing village programs, and improving the quality of performance in village government (Woo, 2005 and Lehman et al., 2019). With this empowerment program, it is hoped that it can improve the performance of the village administration in developing and advancing the village. The community empowerment program in the institutional sector includes all community institutions in the village. This program aims to build institutions that are more directed, productive and organized. This form of an empowerment program can be in the form of training, organizing activities, and improving facilities/infrastructure. The existence of an empowerment program in the institutional sector is expected to improve the performance of institutions so that they can assist village/rural governments in carrying out the wheels of development (Chow et al., 2000, Dacosta \& Carroll, 2001, Ding et al., 2004; Yanget al., 2019). In order to be strong and able to determine their own destiny, a society is not enough to just be awakened and trained in skills, but also must be organized. Organization means that everything is done in an orderly manner, there is a division of tasks among individuals who will be responsible for carrying out their respective tasks and there is a leadership that does not only consist of a few people but leadership at different levels. Tasks must be shared by different groups, including young people, women, and parents. Healthy bookkeeping is also very important. Everyone must know the use of money and what the rest is. Bookkeeping must be routinely controlled, for example, every month to avoid fraud.

\subsection{Village Citizen Welfare}

The village is the forerunner of the formation of a political and government society long before these countries and nations were formed, the social structure of village communities, indigenous peoples and so on, has become a social institution that has a very important position (Demir, 2019, García-Cortijo et al., 
2019 and Ira, 2019). They are autonomous institutions with their own traditions, customs and laws and are relatively independent. Process of political and government reform where the change in the principle of government from centralization to decentralization has implications for the implementation of village government where village governments are given the opportunity to develop with supervision and guidance from the government on it (Findlay et al., 1994, Wu, 1994, Stathopoulou et al., 2004, Berkes \& DavidsonHunt, 2007, Steiner \& Atterton, 2015 and Zhou, 2019).

Village development is an activity process to increase empowerment in achieving a better future. This understanding includes efforts to improve community empowerment even in line with the era of autonomy, the meaning of the concept should be expanded by increasing community empowerment and increasing community participation in the development process (Huang et al., 2019, Maulida \& Rarasati, 2019, RezaeiMoghaddam \& Izadi, 2019 and Zhang, 2020,). Society is the subject of development not an object of development that is able to set goals, control the resources owned and direct the development process to improve its standard of living. This is in line with development policies that are more prioritized to restore the socio-economic life of the community or increase the income of rural communities and uphold the image of local governments in development. The conceptual framework that can be formed as show in Figure 1 as a follows:

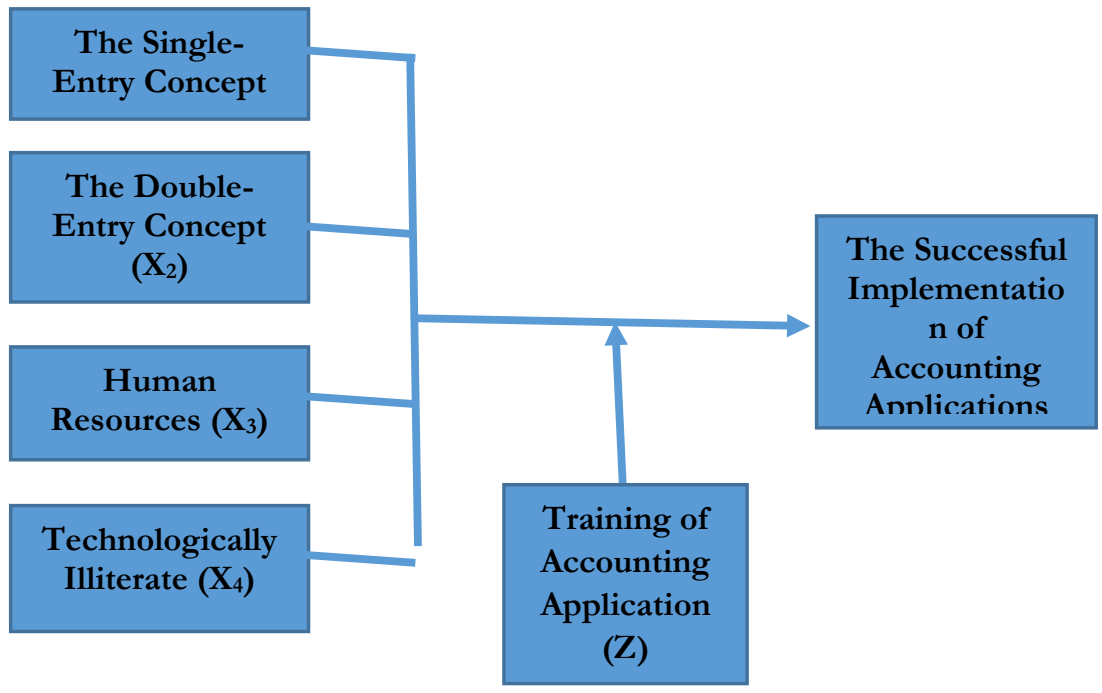

Figure 1. Conceptual Framework

Based on Figure 1 it shows that the Single-Entry Concept variable influences the Successful Implementation of Accounting Applications variable. If the Single Entry principle is applied it will be able to increase the successful application of accounting applications. If a single entry is not implemented, the accounting application will not run. Likewise, if the double entry bookkeeping accounting model is applied it will support the success of the accounting system. In addition, the success of the application of accounting applications will be better if it is supported by adequate human resource factors. Adequate human resources can be obtained with adequate training and knowledge of the application tools. In addition, the success of the application of accounting applications will be better if it is supported by adequate Technologically Illiterate factors. Technologically Illiterate includes adequate hardware and software support. The Training of Accounting Application Variable also plays a role in increasing the ability to apply the accounting application. 


\section{METHOD}

This research investigated Village-Owned Enterprise/rural enterprises (BUMDes) in Indonesia. It is quantitative research as the data used consisted of numbers. The main source of information in this research was the data obtained directly from Village-Owned Enterprises. The data were comprised of primary data. These primary data were obtained by distributing questionnaires to each Village-Owned Enterprise. The research population consisted of the management of rural enterprises all over Indonesia. The research sample consisted of 336 sample in charge of managing finances of rural enterprises. The independent variables in this research consisted of the Understanding of the Single-Entry Concept, Understanding of the Double-Entry Concept, Poor Human Resources, and Technologically Illiterate.

The moderating variable was the Training of Accounting Applications. The dependent variable in this research was the Successful Implementation of Accounting Applications. To analyze the data, this research employed the Structural Equation Model (SEM) analysis method with Partial Least Square (PLS) measurement. The reason for using Smart PLS is because of the outer model testing in which the Structural Equation Modeling model only tests the relationship of indicators with their variables which are reflexive, whereas in PLS it can be reflexive or formative so that determining indicators can be based on theory or adapt indicators that have been used before. The Structural Equation Model is a statistical technique that enables a relatively complex set of relationships to be tested simultaneously or partially. While PLS measurement can be used on any type of data scale (nominal, ordinal, interval or ratio) as well as more flexible assumption requirements. PLS is also used to measure the relationship between each indicator and its construct. In addition, in PLS, a bootstrapping test is also besides performed on the structural models, specifically the outer model and the inner model. Hypothesis testing is presented based on the research objectives. The level of confidence used is $95 \%$ and thus the level of precision or the inaccuracy limit is equal to $(\alpha)=5 \%=0.05$. At table by 1.96 thus is accordingly generated (Ringle et al, 2015), therefore:

a. If the value of $t$ count is greater than $1.96, \mathrm{H} \alpha$ is accepted.

b. If the value of $t$ count is lower than $1.96, \mathrm{H} \alpha$ is rejected.

\section{RESULT AND DISCUSSION}

\subsection{Results}

\subsubsection{Characteristics of Respondents}

General description of respondents determined by researchers relating to data processing in an effort to test hypotheses, such as in terms of distributing questionnaire results, descriptive statistical results, testing hypotheses and discussion, distributing questionnaires conducted by researchers in 2018 by distributing questionnaires returning as many times 336 questionnaires for financial managers. This study uses primary data obtained from questionnaires distributed to 420 respondents and returned 336 questionnaires, in the following Table 1:

Table 1

Level of Taking Questionnaire

\begin{tabular}{|c|l|c|c|}
\hline No. & Notes & Total & Percentage \\
\hline 1 & Questionnaire distributed & 420 & $100 \%$ \\
\hline 2 & Questionnaire received & 336 & $80 \%$ \\
\hline 3 & Missing questionnaire & - & \\
\hline 4 & The questionnaire used in the study & 336 & $80 \%$ \\
\hline
\end{tabular}

Source: own calculation 
Based on Table 1 it can be seen that in BUMDEs financial managers, there were 336 questionnaires returned with a 100\% return rate so that there were 336 questionnaires ready for processing. Based on research data that has been collected, then obtained data about respondents with data characteristics consisting of gender, recent education and years of service. These are listed in the following Table 2:

Table 2

Characteristics of Respondents by Gender

\begin{tabular}{|c|c|c|c|}
\hline No. & Gender & Total & Percentage \\
\hline 1 & Male & 143 & $42.56 \%$ \\
\hline 2 & Female & 193 & $57.44 \%$ \\
\hline & Total & 336 & $100 \%$ \\
\hline
\end{tabular}

Source: own calculation

Based on Table 2 above, show that about the characteristics of respondents based on gender, as many as 143 or $42.56 \%$ of respondents are male and 193 or $57.44 \%$ of respondents are female, while the characteristics of respondents based on the latest education in Table 3 below:

Table 3

Characteristics of Respondents by Education

\begin{tabular}{|c|c|c|c|}
\hline No. & Educational Level & Total & Percentage \\
\hline 1 & Junior High School & 23 & $.6 .85 \%$ \\
\hline 2 & Senior High School & 245 & $72.90 \%$ \\
\hline 3 & Diploma & 23 & $6.85 \%$ \\
\hline 4 & Bachelor & 42 & $12.50 \%$ \\
\hline 5 & Master & 3 & $0.009 \%$ \\
\hline & Total & 336 & $100 \%$ \\
\hline
\end{tabular}

Source: own calculation

Based on Table 3 above regarding the characteristics of respondents based on their last education, it can be seen that 245 respondents or $72.90 \%$ have the last education at the high school level, 23 respondents or $6.85 \%$ have the last education at Diploma, 42 respondents or $12.50 \%$ have the latest education at the undergraduate level. 3 respondents or $0.009 \%$ who have the last education at the Masters level. Characteristics of respondents are based on years of service with BUMDEs, with details in the following Table 4:

Table 4

Characteristics of Respondents Based on Years of Service

\begin{tabular}{|c|c|c|c|}
\hline No & Experience (Years) & Total. & Percentage. \\
\hline 1 & $<1$ & 87 & $25.89 \%$ \\
\hline 2 & $1-2$ & 203 & $60.42 \%$ \\
\hline 3 & $>2$ & 46 & $13.69 \%$ \\
\hline \multicolumn{2}{|c|}{ Total } & 336 & $100 \%$ \\
\hline
\end{tabular}

Source: own calculation

From Table 4 above regarding the characteristics of respondents based on years of service, it can be seen that 87 or $25.89 \%$ of respondents have more than 1 year of service, 203 respondents or $60.42 \%$ have 1-2 years of service, 46 or $13.69 \%$ of respondents have more than 2 years. 


\subsubsection{Descriptive Statistics}

Analyzing the results of research data processing can be seen from the results of descriptive statistics consisting of minimum values, maximum, mean. and standard deviations in the following Table 5.

Table 5

Descriptive statistics

\begin{tabular}{|l|c|c|c|c|c|}
\hline & $\mathrm{N}$ & Min. & Max. & Mean. & Std. Deviation. \\
\hline Understanding of the Single-Entry Concept & 338 & 3 & 15 & 6.91 & 3.19 \\
\hline Understanding of the Double-Entry Concept & 338 & 3 & 15 & 7.43 & 3.10 \\
\hline Poor Human Resources & 338 & 3 & 15 & 6.80 & 3.21 \\
\hline Technologically Illiterate & 338 & 3 & 15 & 7.61 & 3.17 \\
\hline Training in Use Accounting Applications & 338 & 3 & 13 & 6.13 & 2.26 \\
\hline Successful Implementation of Accounting Applications & 338 & 3 & 15 & 9.43 & 3.70 \\
\hline Valid N & 338 & & & & \\
\hline
\end{tabular}

Source: Primary data processed (2018).

Based on Table 5 that the results of the tabulation of data on research conducted with 338 respondents have been collected, it can be seen that the Understanding of the Single-Entry Concept variable has a minimum value of 3 , a maximum of 15 , a mean of 6.91 and a standard deviation of 3.19. In the Understanding of the Double-Entry Concept variable with a minimum value of 3, a maximum of 15, a mean of 7.43 and a standard deviation of 3.10. For the Poor Human Resources variable with a minimum value of 3, a maximum of 15. a mean of 6.80 and a standard deviation of 3.21. In the Technologically Illiterate variable with a minimum value of 3 , a maximum of 15 , a mean of 6.13 and a standard deviation of 2.26. In the Training in Use Accounting Applications variable with a minimum value of 3, a maximum of 13, a mean of 6.13 and a standard deviation of 2.26. In the Successful Implementation of Accounting Applications variable with a minimum value of 3 , a maximum of 15 , a mean of 9.43 and a standard deviation of 3.70 .

\subsubsection{Measurement Testing (Outer Model)}

The outer model was assessed by looking at the convergent validity (the value of the loading factor for each constructed). The loading factor greater than 0.70 is highly recommended, however, the loading factor between 0.50 and 0.60 remains acceptable as long as the model is still in the development stage (Ringle et al., 2015). Based on the data processing in Table 6, the following results are generated:

Table 6

The Loading Factor

\begin{tabular}{|c|c|c|c|c|c|c|c|c|c|c|}
\hline \multicolumn{11}{|c|}{ Outer Loadings } \\
\hline & Effect1 & $\begin{array}{c}\text { Effect } \\
2\end{array}$ & $\begin{array}{c}\text { Effect } \\
3\end{array}$ & $\begin{array}{c}\text { Effect } \\
4\end{array}$ & $\begin{array}{l}\text { Successful } \\
\text { Implementa } \\
\text { tion of } \\
\text { Accounting } \\
\text { Application } \\
\text { s }\end{array}$ & $\begin{array}{l}\text { Training in } \\
\text { Use } \\
\text { Accounting } \\
\text { Application } \\
\text { s }\end{array}$ & $\begin{array}{l}\text { Underst } \\
\text { anding } \\
\text { of the } \\
\text { Single- } \\
\text { Entry } \\
\text { Concept }\end{array}$ & $\begin{array}{l}\text { Understa } \\
\text { nding of } \\
\text { the } \\
\text { Double- } \\
\text { Entry } \\
\text { Concept }\end{array}$ & $\begin{array}{c}\text { Poor } \\
\text { Human } \\
\text { Resourc } \\
\text { es }\end{array}$ & $\begin{array}{l}\text { Technol } \\
\text { ogically } \\
\text { Illiterate }\end{array}$ \\
\hline $\begin{array}{l}\text { Understanding of } \\
\text { the Single-Entry } \\
\text { Concept } * \text { Training } \\
\text { in Use Accounting } \\
\text { Applications }\end{array}$ & & & & 1.195 & & & & & & \\
\hline $\begin{array}{l}\text { Understanding of } \\
\text { the Double-Entry } \\
\text { Concept } * \text { Training }\end{array}$ & & 1.205 & & & & & & & & \\
\hline
\end{tabular}




\begin{tabular}{|c|c|c|c|c|c|c|c|c|}
\hline $\begin{array}{l}\text { in Use Accounting } \\
\text { Applications }\end{array}$ & & & & & & & & \\
\hline $\begin{array}{l}\text { Poor Human } \\
\text { Resources * } \\
\text { Training in Use } \\
\text { Accounting } \\
\text { Applications }\end{array}$ & 1.421 & & & & & & & \\
\hline $\begin{array}{l}\text { Technologically } \\
\text { Illiterate * Training } \\
\text { in Use Accounting } \\
\text { Applications }\end{array}$ & & 1.370 & & & & & & \\
\hline Y11 & & & 0.833 & & & & & \\
\hline Y12 & & & 0.825 & & & & & \\
\hline Y13 & & & 0.945 & & & & & \\
\hline Y14 & & & 0.923 & & & & & \\
\hline Z11 & & & & 0.902 & & & & \\
\hline Z12 & & & & 0.720 & & & & \\
\hline Z13 & & & & 0.913 & & & & \\
\hline $\mathrm{X} 11$ & & & & & 0.923 & & & \\
\hline $\mathrm{X} 12$ & & & & & 0.911 & & & \\
\hline $\mathrm{X} 13$ & & & & & 0.904 & & & \\
\hline $\mathrm{X} 21$ & & & & & & 0.850 & & \\
\hline $\mathrm{X} 22$ & & & & & & 0.774 & & \\
\hline $\mathrm{X} 23$ & & & & & & 0.815 & & \\
\hline $\mathrm{X} 31$ & & & & & & & 0.918 & \\
\hline $\mathrm{X} 32$ & & & & & & & 0.904 & \\
\hline X33 & & & & & & & 0.898 & \\
\hline $\mathrm{X} 41$ & & & & & & & & 0.936 \\
\hline $\mathrm{X} 42$ & & & & & & & & 0.733 \\
\hline $\mathrm{X} 43$ & & & & & & & & 0.925 \\
\hline
\end{tabular}

Source: Results of Data Processing Using SmartPLS 3.0 (2018).

The Table 6 above shows that the loading factor generated a score greater than the recommended score by 0.70 or between 0.50 and 0.60 . It means that indicators used in this research are valid. The following is the loading factor diagram of each indicator of the research model show in Figure 2:

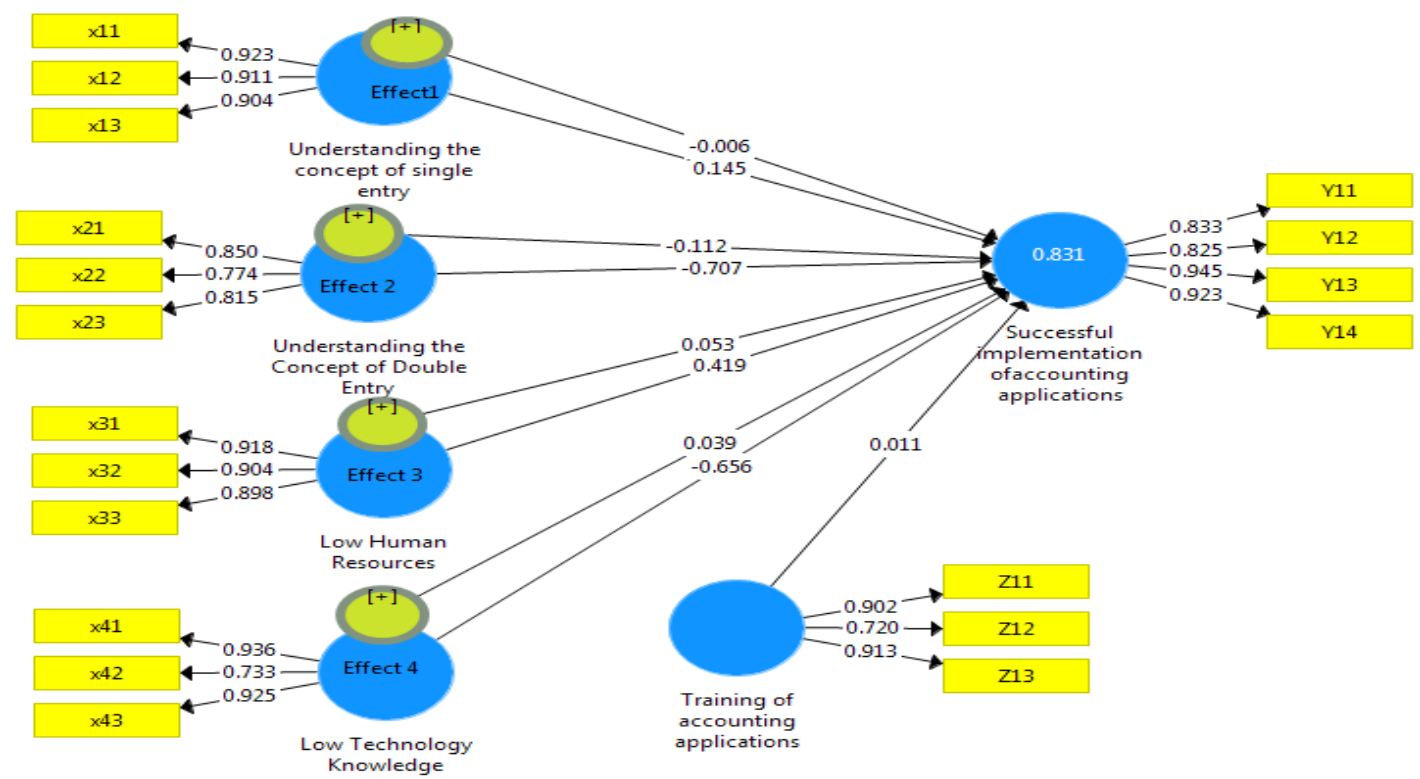

Figure 2. Loading Factor Values

Source: Results of Data Processing Using SmartPLS3.0 (2018). 
Based on Figure 2, it shows that each indicator is above 0.50 . This shows each indicator is fulfilling convergence validity.

\subsubsection{Reliability Test}

The reliability test was undertaken by looking at the indicators measuring the constructs and of all the scores generated, none is smaller than 0.50. Reliability is tested by looking at the scores of the composite reliability and Cronbach's alpha (Ringle et al., 2015). Based on the data processing, the following results are generated in Table 7:

Table 7

Composite Reability

\begin{tabular}{|l|l|}
\hline & Composite Reliability \\
\hline Effect 1 & 1.000 \\
\hline Effect 2 & 1.000 \\
\hline Effect 3 & 1.000 \\
\hline Effect 4 & 1.000 \\
\hline Successful Implementation of Accounting Applications & 0.934 \\
\hline Training in How to Use Accounting Applications & 0.885 \\
\hline Understanding of the Single-Entry Concept & 0.937 \\
\hline Understanding of the Double-Entry Concept & 0.854 \\
\hline Poor Human Resources & 0.933 \\
\hline Technologically Illiterate & 0.902 \\
\hline
\end{tabular}

Source: Results of Data Processing Using SmartPLS 3.0 (2018).

Based on Table 7 shows the value of each variable as Understanding of the Single-Entry Concept $(0.937>0.70)$, Understanding of the Double-Entry Concept $(0.854>0.70)$, Poor Human Resources $(0.933>$ 0.70), Technologically Illiterate $(0.902>0.70)$, Training in Use Accounting Applications $(0.885>0.70)$ and Successful Implementation of Accounting Applications $(0.934>0.70)$. These results indicate that all variables have above value of 0.70 . This shows the consistency and stability of the instruments used high. In other words, all constructs or research variables as measuring instruments are fit. While the Cronbach Alpha value show in Table 8 as a follows :

Table 8

The Cronbach's Alpha Table

\begin{tabular}{|l|c|}
\hline & Cronbach's Alpha \\
\hline Effect 1 & 1.000 \\
\hline Effect 2 & 1.000 \\
\hline Effect 3 & 1.000 \\
\hline Effect 4 & 1.000 \\
\hline Successful Implementation of Accounting Applications & 0.905 \\
\hline Training in How to Use Accounting Applications & 0.808 \\
\hline Understanding of the Single-Entry Concept & 0.900 \\
\hline Understanding of the Double-Entry Concept & 0.749 \\
\hline Poor Human Resources & 0.892 \\
\hline Technologically Illiterate & 0.838 \\
\hline
\end{tabular}

Source: Resultsof Data Processing Using SmartPLS 3.0 (2018).

Based on Table 8 shows that the scores of the composite reliability and Cronbach's alpha for all exogenous and endogenous constructs are highly reliable as all the scores generated are than 0.70. 


\subsubsection{Testing of the Structural Model (Inner Model)}

An outer model that specifies the relationship between latent variables and indicators or their manifest variables (measurement models). Outer models are often called outer relations which define how each block of indicators relates to the latent variables that they form. After the estimated, model has been found to meet the Outer Model criteria, testing of the structural model (inner model) was undertaken afterwards. The inner model functions to explain and specify the relationship between latent variables based on substantive theory. The inner model aims to examine the relationship between constructs and the significance value and the R-Square value. Here is the R-Square value of the construct in Table 9 as a follows:

Table 9

The R-Square Table

\begin{tabular}{|l|l|l|}
\hline \multicolumn{1}{|c|}{ Indicator } & R-Square & $\begin{array}{c}\text { Adjusted R- } \\
\text { Square }\end{array}$ \\
\hline Successful Implementation of Accounting Applications & 0.831 & 0.802 \\
\hline
\end{tabular}

Source: Results of Data Processing Using SmartPLS 3.0 (2018).

On Table 9, it can be seen that the R-Square value for the variable Successful Implementation of Accounting Applications is equal to 0.831 (83.1\%) and adjusted R-Squared value is 0.802 (80.20\%), meaning that the variability of the construct Successful Implementation of Accounting Applications can be explained by the constructs Understanding of the Single-Entry Concept, Understanding of the Double-Entry Concept, Poor Human Resources, and Technologically Illiterate as well as the construct Training in Use Accounting Applications and the interaction between them reaches $83.1 \%$ (for adjusted R-Squared value is $80.20 \%)$.

\subsubsection{Hypothesis Testing}

The hypothesis testing is presented in the following Table 10 as a follows:

Table 10

The Table of Path Coefficients

\begin{tabular}{|l|c|c|c|c|c|}
\hline & $\begin{array}{c}\text { Original Sample } \\
(\mathrm{O})\end{array}$ & $\begin{array}{c}\text { Sample } \\
\text { Mean (M) }\end{array}$ & $\begin{array}{c}\text { Standard } \\
\text { Deviation }\end{array}$ & $t$ Statistics & $p$ Values \\
\hline $\begin{array}{l}\text { Effect 1->Successful Implementation of Accounting } \\
\text { Applications }\end{array}$ & -0.006 & -0.001 & 0.093 & 0.069 & 0.945 \\
\hline $\begin{array}{l}\text { Effect 2 ->Successful Implementation of Accounting } \\
\text { Applications }\end{array}$ & -0.112 & -0.116 & 0.125 & 0.894 & 0.372 \\
\hline $\begin{array}{l}\text { Effect 3->Successful Implementation of Accounting } \\
\text { Applications }\end{array}$ & 0.053 & 0.053 & 0.121 & 0.442 & 0.659 \\
\hline $\begin{array}{l}\text { Effect 4->Successful Implementation of Accounting } \\
\text { Applications }\end{array}$ & 0.039 & 0.036 & 0.084 & 0.458 & 0.647 \\
\hline $\begin{array}{l}\text { Training in How to Use Accounting Applications - } \\
\text { >Successful Implementation of Accounting } \\
\text { Applications }\end{array}$ & 0.011 & 0.013 & 0.061 & 0.182 & 0.856 \\
$\begin{array}{l}\text { Understanding of the Single-Entry Concept - } \\
\text { >Successful Implementation of Accounting } \\
\text { Applications }\end{array}$ & 0.145 & 0.140 & 0.102 & 1.414 & 0.158 \\
\hline $\begin{array}{l}\text { Understanding of the Double-Entry Concept - } \\
\text { >Successful Implementation of Accounting } \\
\text { Applications }\end{array}$ & -0.707 & -0.697 & 0.099 & 7.164 & 0.000 \\
\hline $\begin{array}{l}\text { Poor Human Resources ->Successful Implementation } \\
\text { of Accounting Applications }\end{array}$ & 0.419 & 0.418 & 0.119 & 3.534 & 0.000 \\
\hline $\begin{array}{l}\text { Technologically Illiterate ->Successful Implementation } \\
\text { of Accounting Applications }\end{array}$ & -0.656 & -0.663 & 0.068 & 9.653 & 0.000 \\
\hline
\end{tabular}

Source: Results of Data ProcessingUsingSmartPLS3.0 (2018). 
On Table 10, the test of relationships between constructs suggests that the construct understanding of the Single-Entry concept has no effect on the successful implementation of Accounting Applications; the construct understanding of the Double-Entry concept has a negative effect on the Successful Implementation of Accounting Applications with the parameter coefficient value by -0.707 and a level of significance by $5 \%$ (the value of $t$ count is greater than 1.96). The results show that all four variables are not significant if strengthened by moderating variables. The following is a diagram illustrating the $t$-statistic values based on the output using SmartPLS 3.0 in Figure 3 as a follows :

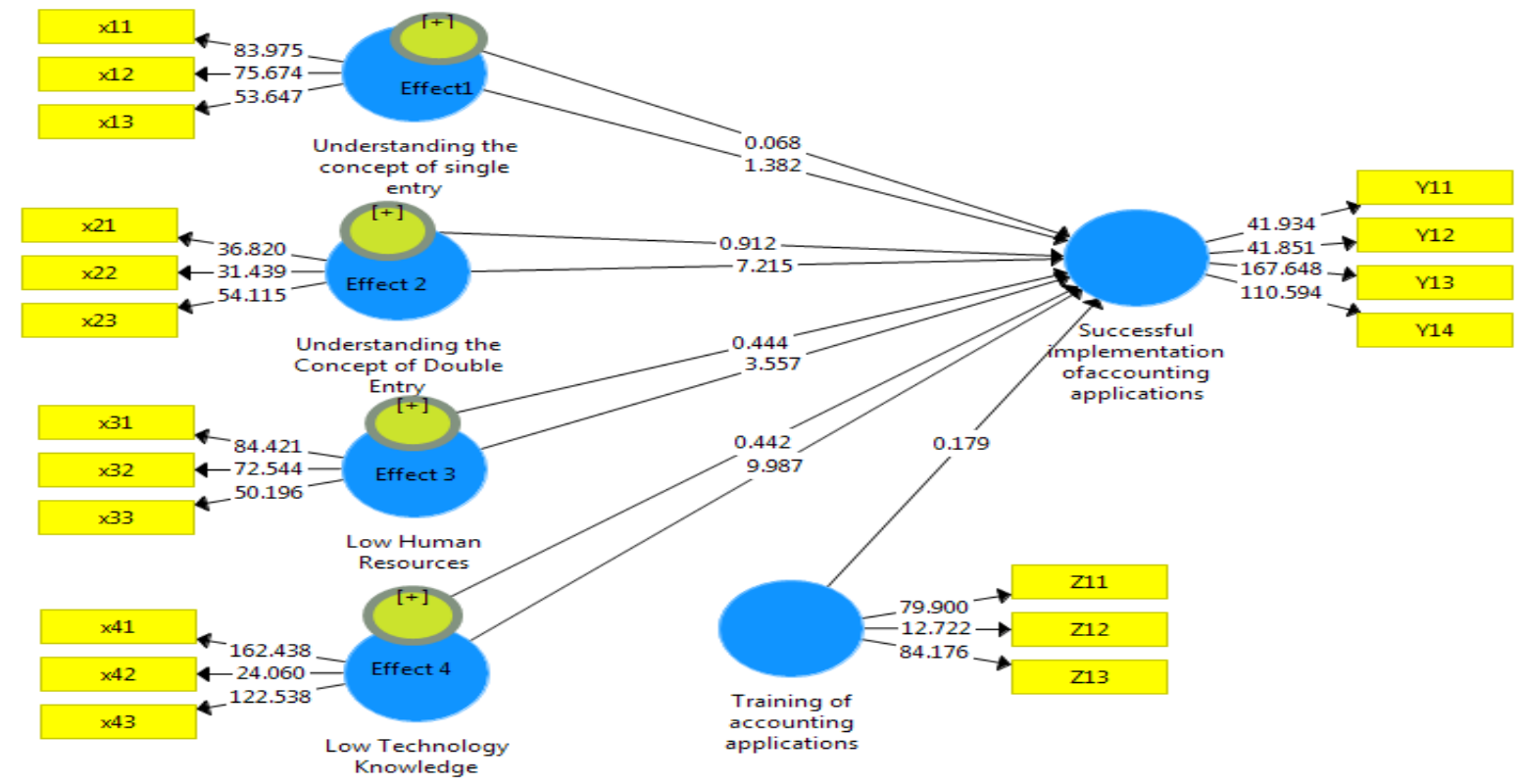

Figure 3. Output Bootstrapping

Source: Results of Data Processing UsingSmartPLS 3.0 (2018).

Figure 3 shows the resampling of data in completing the statistics of the size of a sample represents actual population data. The construct of Human Resources has a positive effect on the Successful Implementation of Accounting Applications with the parameter coefficient value by 0.419 and a level of significance by $5 \%$; the construct of Technologically Illiterate has a negative effect on the successful implementation of Accounting Applications with the parameter coefficient value by -0.656 and a level of significance by 5\%; while the construct of Training in Use Accounting Applications has no effect on the Successful Implementation of Accounting Applications. The construct the interaction between understanding of the Single-Entry concept, understanding of the Double-Entry concept, Human Resources, Technologically Illiterate and Training in use Accounting Applications does not affect the successful implementation of Accounting Applications. Thus, it can be concluded that there is no relationship in the form of moderation or the construct of Training in Use Accounting Applications is not a moderating.

\section{DISCUSSION}

Rural enterprises required the development of managerial capacity for its managers. BUMDes managers need knowledge about planning, product development, marketing, human resources management, financial records according to accounting standards, and looking for investors. Each Village Government provides "goodwill" in response to the establishment of rural enterprises. As one of the economic institutions operating in rural areas, Rural enterprises must have differences with economic institutions in general. This is intended so that the existence and performance of Rural enterprises can contribute 
significantly to improving the welfare of the villagers. Besides that, so as not to develop a capitalistic business system in the countryside that can lead to disruption of the values of social life. The establishment and management of Village-Owned Enterprises is a manifestation of village productive economic management carried out cooperatively, participatory, emancipatory, transparency, accountable, and sustainable. Therefore, a serious effort is needed to make the management of the business entity run effectively, efficiently, professionally and independently.

To achieve the goals of Rural enterprises, it is carried out by fulfilling the (productive and consumptive) needs of the community through the distribution of goods and services managed by the community and rural regulation. The fulfillment of this need is sought not to burden the community, considering that Rural enterprises will be the most dominant village business in driving the village economy. This institution is also required to be able to provide services to non-members (outside the village) by placing prices and services that apply market standards. This means that there are mutually agreed upon institutional/regulatory mechanisms, so as not to cause economic distortions in rural areas due to businesses run by Rural enterprises.

The Rural enterprises can be established according to the needs and potential of the village. What is meant by "village needs and potential" are: a. Community needs, especially in meeting basic needs; b. Village resources are available that have not been utilized optimally, especially village wealth and there is demand in the market; c. Available human resources are able to manage business entities as assets that drive the economy of the community; $\mathrm{d}$. The existence of business units which are the economic activities of the community members which are managed partially and are not accommodated; BUMDes is a vehicle for running a business in the village. What is meant by "village business" is a type of business that includes village economic services such as: a. Financial services business, land and water transportation services, village electricity, and other similar businesses; b. Distribution of nine basic ingredients of the village economy; c. Trade in agricultural products includes food crops, plantations, livestock, fisheries and agribusiness; d. Industrial and folk crafts. The involvement of the village government as the largest source of capital for Rural enterprises or as a founder and community is expected to be able to meet the Minimum Service Standards, which are manifested in the form of protection for adverse intervention from third parties (both inside and outside the village). Likewise, village governments have a role in establishing Rural enterprises as legal entities that are based on the prevailing laws and regulations, and in accordance with the agreements built in the village community. Further regulation regarding Rural enterprises is regulated through Regional Regulation after observing the regulations above. Through the mechanism of self help and member-base, the Rural enterprises are also an embodiment of village community participation as a whole, so as not to create a business model that is hegemony by certain groups at the village level. That is, this regulatory system is manifested in a solid institutional mechanism. Strengthening institutional capacity will be directed at the existence of rules that bind all members (one for all).The management of professional, accountable and transparent Village-Owned Enterprises is very much needed. So that all Rural enterprises income and expenses must be booked properly.

The community empowerment program on the economy that is driven by village companies is a government program to improve the village economy. This program includes the empowerment of SMEs, home industries, farmer groups, markets, and other economic support communities (Warner, 1995, Okpukpara, 2009, Pham and Matsunaga, 2019). The form of this empowerment program can be in the form of training, workshops, capital, production equipment assistance, improvement of facilities/infrastructure and others. With the existence of community empowerment in the economic field, it is expected to increase the economy and the welfare of the community. The community empowerment program in the field of technology is a village government program in keeping up with the times. In addition, the use of technology can also improve performance to be faster and more accurate. This form of empowerment program can be 
in the form of training, technology development, and use of technology in the work process and community life. The existence of community the empowerment in the field of technology is expected to increase the competitiveness of the community, facilitate the community in working, and facilitate the public to share and obtain information.

\section{CONCLUSIONS AND SUGGESTIONS}

\subsection{Conclusions}

Based on research result and discussion, there are conclusions:

1. The construct understanding of the Single-Entry concept has no effect on the successful implementation of Accounting Applications. The relevant agencies and ministries are expected to increase the training activities of the concept of Single Entry to the financial management officer of the Village Business Entity and connect with technological guidance so that it will increase the insight and knowledge of the rural enterprise management officers so that they can better carry out their duties and responsibilities.

2. The construct understanding of the Double-Entry concept has a negative effect on the successful implementation of Accounting Applications. Relevant agencies and ministries are expected to apply the Double Entry concept to every activity carried out by rural enterprise management officers together with village communities in an effort to improve the village economy, in this case providing training in developing village-owned enterprises so that they are more advanced.

3. The construct low/lack of Human Resources has a positive effect on the successful implementation of Accounting Applications. The quality of human resources influences the process of implementing a village accounting system where based on the results of research with a high school education level dominates the level of education of respondents and the existence of training that is able to improve the ability of village officials so that they can complete tasks and responsibilities well, with an increase in expertise that is a the indicator part increases the quality of human resources in this case to carry out the tasks and responsibilities that exist in the village apparatus so that it will be easier to complete the work on time with effective and efficient performance results where the village apparatus has its own government system in achieving the goals set by the government center in advancing the village.

4. The construct technologically Illiterate has a negative effect on the successful implementation of Accounting Applications. The latest technology transfer processes in rural enterprise operations must be implemented because technological developments are developing rapidly and dynamically and are soon to be adopted. The development of payment systems with Bar Code and E-Money must be properly controlled by the officers.

5. The construct training in use Accounting Applications has no effect on the successful implementation of Accounting Applications. The ability or expertise of human resources in the entity must be in the presence of provisions that can improve expertise such as the existence of training, appropriate levels of education and expertise as well as the experience that can improve the capabilities and expertise possessed.

6. The interaction between construct of understanding of the Single-Entry concept, understanding of the Double-Entry concept, low/lack human resources, technologically 
Illiterate and training in use Accounting Applications does not affect to the successful implementation of Accounting Applications.

7. The construct Training in use Accounting Applications is not a moderating effect. Training does not act as a moderating variable because the single entry, double entry and technology systems are indeed not implemented at all and merely follow the training without implementation.

\subsection{Suggestions}

Based on the conclusions above, the following suggestions are offered:

1. Future researchers are advised to expand or add variables related to the successful implementation of accounting applications in order to improve findings of this research.

2. Village-Owned Enterprises (BUMDes) included as the subject of this research are advised to greater attention to the aspect of human resources. Human resources competence will greatly support the successful implementation of offline accounting applications as competent human resources can understand accounting and master technology so that financial statements to be produced are better in terms of quality.

Findings of this research for practitioners as a source of information and considerations in policy making, providing contribution to accounting practices in Indonesia in the future, and providing insights and information to Village-Owned Enterprises in an attempt to develop and improve understanding of financial statements, and second, for academicians, in which findings of this research are expected to help develop accounting in general and government accounting in Indonesia in particular.

\section{ACKNOWLEDGEMENT}

This research is an independent study that is not funded by any institution and just of sharing between authors.

\section{REFERENCES}

Adisasmita, R. (2006). Rural and Urban Development. Yogyakarta. Graha Ilmu Publishers. https://www.worldcat.org/title/pembangunan-pedesaan-danperkotaan/oclc/191671459? referer=di\&ht=edition

Berkes, F., \& Davidson-Hunt, I. J. (2007). Communities and social enterprises in the age of globalization. Journal of enterprising communities: people and places in the global economy, 1(3), 209-221. https://doi.org/10.1108/17506200710779521

Budiono, P. (2015). Implementation of Policy for Village-Owned Enterprises (BUMDes) in Bojonegoro (Study in Ngringinrejo Village, Kalitidu District and Kedungprimpen Village, Kanor District). Young Political Juurnal. 4(1).45-57. http://www.journal.unair.ac.id/download-fullpapers-jpm3cd22097c1 full.pdf

Çetinel, F., Yolal, M., \&Emeksiz, M. (2008). Human resources management in small-and medium-sizedhotels in Turkey. Journalof Human Resources in Hospitalitye Tourism, 8(1), 43-63. https://doi.org/10.1080/15332840802274437

Cheah, J., Amran, A., \& Yahya, S. (2019). Internal oriented resources and social enterprises' performance: How can social enterprises help themselves before helping others?. Journal of Cleaner Production, 211, 607-619. https://doi.org/10.1016/j.jclepro.2018.11.203

Chow, I. H. S., \& Fu, P. P. (2000). Change and development in pluralistic settings: an exploration of HR practices in Chinese town ship and village enterprises. International Journalof Human Resource Management, 11(4), 822-836. https://doi.org/10.1080/09585190050075141 
Cunningham, L. X., \& Rowley, C. (2008). The development of Chinese small and medium enterprisesand human resource management: A review. Asia Pacific Journalof Human Resources, 46(3), 353-379. https://doi.org/10.1177/1038411108095763

Dacosta, M., \& Carroll, W. (2001). Town ship and village enterprises, openness and regional economic growth in China. Post-Communist Economies, 13(2), 229-241. https://doi.org/10.1080/14631370120052681

Demir, O. (2019). Digital Skills, Organizational Behavior and Transformation of Human Resources: A Review. Ecoforum Journal, 8(1). 34-47. http://www.ecoforumjournal.ro/index.php/eco/article/view/931/553

Ding, D. Z., Ge, G., \& Warner, M. (2004). Evolution of organizational governance and human resource management in China's township and village enterprises. The International Journalof Human Resource Management, 15(4-5), 836852. https://doi.org/10.1080/0958519042000192979

Ding, D. Z., Lan, G., \& Warner, M. (2001). A new form of Chinese human resource management? Personneland labour-management relations in Chinese township and village enterprises: A case-study approach. Industrial Relations Journal, 32(4), 328-343. https://doi.org/10.1111/1468-2338.00202

Findlay, C., Watson, A., \&Wu, H. X. (1994). Ruralenterprises in China: overview, issues and prospects. In Rural enterprises in China (pp. 173-190). Palgrave Macmillan, London. https://doi.org/10.1007/978-1-349-23609-1 9

García-Cortijo, M. C., Castillo-Valero, J. S., \& Carrasco, I. (2019). Innovation in rural Spain. What drives innovation in the rural-peripheral areas of southern Europe?.Journal of Rural Studies. https://doi.org/10.1016/j.jrurstud.2019.02.027

Ghorbel, J. (2019). A Study of Contingency Factors of Accounting Information System Design in Tunisian SMIs. Journal of the Knowledge Economy, 10(1), 74-103. https://doi.org/10.1007/s13132-016-0439-8

Hanh, P. T. M. (2019). Human Resource in Agricultural enterprises in Industry 4.0 A Case of Thai Nguyen Province, Vietnam. Journal Business of School, 60(1). 56-69. https://doi.org/10.26677/TR1010.2019.67.

Ho, N. S., Do, H. H., Hoang, H. N., Van Nguyen, H., Nguyen, D. T., \& Pham, T. T. (2019). Assessment of the Quality of Growth with Respect to the Efficient Utilization of Material Resources. In International Econometric Conference of Vietnam (pp. 660-677). Springer, Cham. https://doi.org/10.1007/978-3-030-04200-4 46

Holsapple, C., Sena, M., \& Wagner, W. (2019). The perceived success of ERP systems for decision support. Information Technology and Management, 20(1), 1-7. https://doi.org/10.1007/s10799-017-0285-9

Huang, L. C., Gao, M., \& Hsu, P. F. (2019). A Study on the Correlation among Human Resource Flexibility Strategy, Organizational Citizenship Behavior, and Organizational Performance in Ecotourism Industry. Ekoloji, 28(107), 379-383. http://www.ekolojidergisi.com/article/a-study-on-the-correlation-amonghuman-resource-flexibility-strategy-organizational-citizenship-5662

Ira, V. (2019). Impact of Rural Restructuring on theTime-Space Behavioural. Rural Areas Between Regional Needsand Global Challenges: Transformation in Rural Space, 4, 17-29. https://doi.org/10.1007/978-3-030-04393-3 2

Kimando, L. N., Sakwa, M., \& Njogu, M. G. W. (2012). Impact of business development services on enterprises in rural Kenya: A case study of micro and small enterprises in Muranga Town. International Journal of Business and Commerce, 1(9), 149-165. https://pdfs.semanticscholar.org/04a2/219d12da6ace69ed678bfb9ea71ef993dafd.pdf

Kimbu, A. N., Ngoasong, M. Z., Adeola, O., \& Afenyo-Agbe, E. (2019). Collaborative networks for sustainable human capital management in women's tourism entrepreneurship: The role of tourism policy. Tourism Planning \& Development, 16(2), 161-178. https://doi.org/10.1080/21568316.2018.1556329

Knight, J., Song, L., \& Huaibin, J. (1999). Chinese rural migrants in urban enterprises: Three perspectives. The Journal of Development Studies, 35(3), 73-104. https://doi.org/10.1080/00220389908422574

Lyon-Hill, S., Cowell, M., Tate, S., \& Alwang, A. (2019). Barriers and Drivers to Accessing and Using Workforce and Technical Assistance Resources for Small and Medium Manufacturers (SMMs) in Rural Regions. Economic Development Quarterly, 33(1), 51-60. https://doi.org/10.1177/0891242418816380

Maulida, L., \& Rarasati, A. D. (2019). Community involvement analysis for sustainable rural infrastructure development. In MATEC Web of Conferences (Vol. 276, p. 02003). EDP Sciences. https://doi.org/10.1051/matecconf/201927602003

McDonagh, P., \& Commins, P. (1999). Food chains, small-scale food enterprises and rural development: Illustrations from Ireland. International Planning Studies, 4(3), 349-371. https://doi.org/10.1080/13563479908721747 
Minister of Home Affairs Regulation (2010). Minister of Home Affairs Regulation Number 39 of 2010 concerning Village-Owned Enterprises. Republic of Indonesia. Jakarta.

Muhammad, K., Mastuki, N. A., Darus, F., \& Ghani, E. K. (2019). Accounting Information System Change in an Agriculture Company: Examination Using Burns and Scapens Framework. Journal of International Studies, 12(1), 105-118. https:/ / www.ceeol.com/search/article-detaillid=787132

Nurlina, Hanuma, N , Safuridara, (2019). Analysis of Structural Poverty Trend Among Rice Farmers in East Aceh Regency, Indonesia. Global Business \& Finance Review, 24(1). 71-79. DOI:10.17549/GBFR.2019.24.1.71

Okpukpara, B. (2009). Strategies for effective loan delivery to small scale enterprises in rural Nigeria. Journal of Development and Agricultural Economics, 1(2), 041-048. https://academicjournals.org/journal/JDAE/articleabstract/DC2EECE3643

Pham, T. T. T., \& Matsunaga, N. (2019). Product and Process Innovation of Micro, Small and Medium Manufacturing Enterprises in Vietnam. In Innovation in Developing Countries (pp. 23-51). Springer, Singapore. https://doi.org/10.1007/978-981-13-3525-9 2

Psychogios, A., \& Prouska, R. (2019). Managing People in Smalland Medium Enterprises in Turbulent Contexts. Routledge.

Purnamasari, H.Y, Eka. R \& Rachmat. (2016). Effectiveness of Management of Village-Owned Enterprises (BUMDes) Based on Community Economy in Warung Bambu Village, Kerawang Timur District, Karawang Regency. Indonesiana Political Journal. 1(2). 35-47. https://doi.org/10.35706/jpi.v1i2.616

Republic of Indonesia (2014). Village Government ismandated in the Law No. 6 of 2014 . Jakarta. http://extwprlegs1.fao.org/docs/pdf/ins161827.pdf

Rezaei-Moghaddam, K., \& Izadi, H. (2019). Entrepreneurship in small agricultural quick-impact enterprises in Iran: development of an index, effective factors and obstacles. Journal of Global Entrepreneurship Research, 9(1), 17-31. https://doi.org/10.1186/s40497-018-0133-3

Ringle, Christian M., Wende, Sven, \& Becker, Jan-Michael. (2015). SmartPLS 3. Bönningstedt: SmartPLS. Retrieved from http://www.smartpls.com

Stathopoulou, S., Psaltopoulos, D., \& Skuras, D. (2004). Ruralentrepreneurship in Europe: A researchframeworkand agenda. International Journal of Entrepreneurial Behavior \& Research, 10(6), 404-425. https://doi.org/10.1108/13552550410564725

Steiner, A., \& Atterton, J. (2015). Exploring the contribution of rural enterprises to local resilience. Journal of Rural Studies, 40, 30-45. https://doi.org/10.1016/j.jrurstud.2015.05.004

Su, M. M., Wall, G., Wang, Y., \& Jin, M. (2019). Livelihood sustainability in a rural tourism destination-Hetu Town, Anhui Province, China. Tourism Management, 71, 272-281. https://doi.org/10.1016/j.tourman.2018.10.019

Tang, L. (2019). Development andImplementationofthe "Outlinefor Development-Oriented Poverty Reduction for China's Rural Areas (2011-2020)". In The Evolution of China's Poverty Alleviation and Development Policy (20012015) (pp. 45-70). Springer, Singapore. https://doi.org/10.1007/978-981-13-1690-6 2

Vixathep, S., Luong, V. K., \& Matsunaga, N. (2019). Entrepreneurial Human Capital, Innovation and Productivity in Small and Medium Manufacturing Enterprises in Vietnam. Innovation in Developing Countries (pp. 53-76). Springer, Singapore. https://doi.org/10.1007/978-981-13-3525-9 3

Warner, M. (1995). The management of human resources in Chinese industry (p. 13). New York: St. Martin's Press. https://link.springer.com/book/10.1057\%2F9780230380066

Wei, Q., \& Li, H. (2019). The Government and Rural Collective Enterprises. In Entities and Structures in the Embedding Process (pp. 115-169). Springer, Singapore. https://doi.org/10.1007/978-981-13-2390-4 4

Williams, S. D. (2019). Climate Change and Preparations for the Tide of Traumatic Stress: Implications for Asia-Pacific Human Resources. Journal of Asia-Pacific Business, 1-17. https://doi.org/10.1080/10599231.2019.1572425

Woo, W. T. (2005). China's Rural Enterprises in Crisis: The Role of In adequate Financial Intermediation. Financial Sector Reform in China, Harvard, http:/ / citeseerx.ist.psu.edu/viewdoc/download?doi=10.1.1.543.9827\&rep=rep1\&type=pdf

Wu, H. X. (1994). The rural industrial enterprise workforce. In Ruralenterprises in China (pp. 117-147). Palgrave Macmillan, London. https://doi.org/10.1007/978-1-349-23609-1 7 
Xheneti, M., Madden, A., \& Thapa Karki, S. (2019). Value of Formalization for Women Entrepreneurs in Developing Contexts: A Review and Research Agenda. International Journal of Management Reviews, 21(1), 3-23. https://doi.org/10.1111/ijmr.12172

Yang, X., Li, H., Chen, W. M., \&Fu, H. (2019). Corporate Community Involvement and Chinese Rural Tourist Destination Sustainability. Sustainability, 11(6), 1574. https://doi.org/10.3390/su11061574

Young, R. (1993). Policy biases, small enterprises and development. Small Enterprise Development, 4(1), 4-15. http://documents1.worldbank.org/curated/en/652031468741329732/585559324 200409289103649/additi onal/multi-page.pdf

Zhang, D., Gao, W., \& Lv, Y. (2020). The Triple Logic and Choice Strategy of Rural Revitalization in the 70 Years since the Founding of the People's Republic of China, Based on the Perspective of Historical Evolution. Agriculture, 10(4), 125. https://doi.org/10.3390/agriculture10040125

Zhang, X., Fan, S., Zhang, L., \&Huang, J. (2004). Local governance and public goods provision in rural China. Journal of public economics, 88(12), 2857-2871. https://doi.org/10.1016/j.jpubeco.2003.07.004

Zhang, X., Hu, L., Salimath, M., \& Kuo, C. C. (2019). Developing Evaluation Frameworks for Business Models in China's Rural Markets. Sustainability, 11(1), 118. https://doi.org/10.3390/su11010118.

Zhou, Y. (2019). Study on the Promotion of Rural Tourism in China's Ethnic Minority Areas Taking Inner Mongolia Autonomous Region as anExample. In 3rd International Seminar on Education Innovationand Economic Management (SEIEM 2018). Atlantis Press. https://doi.org/10.2991/seiem-18.2019.36

Zhu, C. J., \& Warner, M. (2019). The emergence of Human Resource Management in China: Convergence, divergence and contextualization. Human Resource Ranagement Review, 29(1), 87-97. https://doi.org/10.1016/j.hrmr.2017.11.002

Zubović, J., \& Jovanović, O. (2019). Smalland Medium Enterprises in Selected SEE Countries: a Driver of Rural Development. http://www.iep.bg.ac.rs/images/stories/izdanja/Tem 